\title{
Mikrobna stabilnost kobasičarskih proizvoda sa smanjenim udjelom soli
}

\author{
L. Zemljak*, J. Ranilović, A. Đ. Zuber, V. Popijač, J. Madić i L. Kozačinski
}

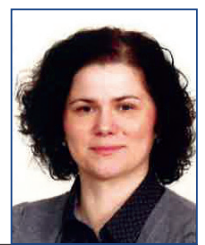

\section{Sažetak}

Cilj ovog rada je validacija roka trajnosti proizvoda sa smanjenim udjelom soli i korištenjem zamjene za sol, s obzirom na njegovu mikrobiološku stabilnost. Mikrobiološke analize su provedene na Kranjskoj kobasici koja je predstavnik skupine polutrajnih kobasičarskih proizvoda. Kontrolni uzorak je proizvod proizveden prema dosadašnjoj „,klasičnoj“ recepturi. Deset pakovina kontrolnog uzorka je analizirano odmah nakon vakuumiranja, zatim sredinom deklariranog roka trajanja (35. dan u roku), na dan isteka roka (45 dana od datuma proizvodnje) i 65. dan od datuma proizvodnje. Svi navedeni uzorci su analizirani i dva dana nakon otvaranja pakovina i čuvanja u hladnjaku na propisanoj temperaturi. Na taj se način validira i način konzumacije proizvoda deklariran na pakovini (nakon otvaranja upotrijebiti u roku 2 dana). Na isti je način ispitana i Kranjska kobasica sa smanjenim udjelom soli. Istraživanjem je obuhvaćena pretraga na sljedeće mikroorganizme: aerobne mezofilne bakterije, Enterobacteriaceae, koagulaza pozitivne stafilokoke/S. aureus, Salmonella spp., bakteriju Listeria monocytogenes i sulfitreducirajuće klostridije. $\mathrm{U}$ analizi navedenih pokazatelja korištena je ISO metodologija. Ispitivanje mikrobne

stabilnosti proizvoda sa smanjenim udjelom soli, provedeno je kroz 140 mikrobioloških analiza. U uzorcima sa smanjenim udjelom soli te $\mathrm{u}$ kontrolnim uzorcima nisu izolirane bakterije roda Salmonella, L. monocytogenes, niti je zabilježen porast ostalih pretraživanih mikroorganizama, osim aerobnih mezofilnih bakterija. Prema dobivenim vrijednostima aerobnih mezofilnih bakterija, tri uzorka (4\%) proizvedena prema „,klasičnoj“ recepturi daju prihvatljiv rezultat, doksekod petuzoraka (7\%) sa smanjenim udjelom soli rezultati analize tumače prihvatljivima prema odredbama propisa. Analiza svih preostalih uzoraka je zadovoljavajuća te nije dobiven niti jedan nezadovoljavajući rezultat. Svi analizirani uzorci su mikrobiološki ispravni tijekom cijelog roka trajnosti proizvoda. Smanjeni udio soli u proizvodu korištenjem zamjene za sol $\left(\right.$ Salut $\left.{ }^{\circledR}\right)$, nije utjecao na mikrobnu stabilnost proizvoda. Odsutnost patogenih mikroorganizama $\mathrm{u}$ analiziranim uzorcima potvrda je uređenog sustava sigurnosti hrane, poštivanja HACCP principa te kontinuiranog provođenja dobre proizvođačke i dobre higijenske prakse.

Ključne riječi: mikrobna stabilnost, kobasičarski proizvodi, smanjeni udio soli, zamjena za sol, aerobne mezofilne bakterije

Lidija ZEMLJAK*, univ. mag. med. vet., (dopisni autor, e-mail: Lidija.Zemljak@podravka.hr), dr. sc. Jasmina RANILOVIĆ, znanstvena suradnica, dr. sc. Andreja Đurica ZUBER, mr. sc. Vesna POPIJAČ, Podravka d.d. Koprivnica, Hrvatska; dr. sc. Josip MADIĆ, dr. med. vet., akademik, dr. sc. Lidija KOZAČINSKI, dr. med. vet., redovita profesorica, Veterinarski fakultet Sveučilišta u Zagrebu, Hrvatska 


\section{Uvod}

Uobičajen unos kuhinjske soli visok je $u$ razvijenim zemljama i premašuje količine potrebne za normalno funkcioniranje organizma. Kaić-Rak i sur. (2009.) navode da u prosjeku unosimo oko $200 \%$ više soli u odnosu na preporučene dnevne količine. Procjenjuje se da u Hrvatskoj prosječan dnevni unos soli po osobi iznosi 11,6 g dok bi po preporuci Svjetske zdravstvene organizacije trebao biti manji od 5 grama. Prepreka smanjivanju unosa kuhinjske soli temelji se na činjenici da 75 - $80 \%$ kuhinjske soli unosimo bez znanja, putem tzv. skrivenih izvora. To su najvećim dijelom polugotovi i gotovi prehrambeni proizvodi, dok manji udio kuhinjske soli dodajemo u hranu sami (Reiner i Jelaković, 2010.).

Strateški plan za smanjenje prekomjernog unosa kuhinjske soli u Republici Hrvatskoj 2015.-2019. donesen je 2014. godine. Hrvatska se ovim dokumentom priključila svjetskom pokretu (WASH World Action on Salt and Health) koji poziva multinacionalne kompanije da smanje količinu soli u proizvodima sukladno preporukama Svjetske zdravstvene organizacije, jer prekomjeran unos kuhinjske soli povećava rizik od srčanih, moždanih i bubrežnih bolesti (Anonymous, 2014.a). Strateški plan ima za cilj postupno smanjenje dnevnog unosa kuhinjske soli u populaciji RH za prosječno $4 \%$ godišnje. Mesne prerađevine su ovim planom definirane kao jedna od prioritetnih skupina hrane $\mathrm{u}$ kojoj je potrebno provoditi smanjenje udjela soli, a jedan od postavljenih ciljeva je i razvoj novih receptura u prehrambenoj industriji (Anonymous, 2014.b,c).

Industrijska proizvodnja hrane je nužno povezana s uporabom soli. Kao polifunkcionalni dodatak sol oblikuje okus proizvoda i pojačivač je okusa (arome), utječe na teksturu proizvoda (mekoća, sočnost), a djeluje i kao konzervans pa utječe na sigurnost proizvoda. Soljenjem se smanjuje sadržaj vode u hrani, što nepovoljno utječe na rast i razmnožavanje najvećeg broja bakterija, odnosno na mikrobiološku ispravnost proizvoda. Kada je koncentracija soli iznad $10 \%$ usporen je razvoj većine mikroorganizama. Iznimka su halofilni mikroorganizmi koji rastu u okolišu s koncentracijom soli 15 - 20 \% (Doko Jelinić i sur., 2010.).

U preradi mesa moguće je smanjiti udio dodane soli, zamijeniti kuhinjsku sol s drugim kloridnim solima, zamijeniti dio nekloridnim solima (fosfati), promijeniti tehnološki proces, poboljšati svojstva soli (veličina i oblik kristala) ili kombinirati neke od navedenih pristupa (Žlender, 2009.). Neke od mogućih zamjena za sol su kalijev klorid, magnezijev klorid, magnezijev sulfat, glutaminska kiselina, kalijev glutaminat, kalijev klorid (Reddy i Marth, 1991., Gelabert i sur., 2003., Bidlas i Lambert, 2008., Alino i sur., 2010., Cepanec i sur., 2017.). Međutim, smanjenjem udjela soli bez dodatka drugih sredstava $s$ konzervirajućim učinkom, smanjuje se trajnost proizvoda.

Razvoj mesnih proizvoda s niskim sadržajem soli nije jednostavan, jer osim na stabilnost i tehnološka svojstva, sol utječe i na aromu proizvoda koju potrošači prepoznaju i očekuju. Ruusunen i Poulanne (2005.) navode da je sadržaj soli do 1,4 \% u toplinski obrađenim kobasicama dovoljan da se $u$ proizvodu dobije toplinski stabilan gel, čvrstoća i vezanje vode. Desmond (2006.) navodi da smanjenje $\mathrm{NaCl}$ za $50 \%$, na udio od 1,25\%, ili zamjena s $\mathrm{KCl}$ ili $\mathrm{MgCl}_{2}$ u mljevenoj svinjetini, ne utječe značajno na ukupni broj mikroorganizama, ali je važno ispitati rok trajnosti i sigurnost mesnih proizvoda nakon što se smanji udio soli ili uvode zamjene za sol.

Iako su natrij i litij (koji se zbog svoje toksičnosti ne koristi u prehrani) jedini 
poznati kationi koji daju čisti slani okus hrani, i kalij utječe na slanost. Stoga se korištenjem kalijevih soli može smanjiti udio natrija u namirnicama, i to tako da potrošači ne osjete smanjeni udio soli, odnosno manju slanost proizvoda (Keast, 2010.). Kalijev klorid kao zamjena za natrijevu sol, smanjuje slanost hrane, ali $u$ velikim koncentracijama može rezultirati metalnim ili gorkim okusom proizvoda (Liem i sur., 2011., Cepanec i sur., 2017.).

U odnosu na navedeno, prehrambena kompanija Podravka d.d. razvila je Nutritivnu strategiju 2014. - 2024. koja je usmjerena na smanjenje udjela za zdravlje negativnih nutrijenata (soli, šećera i masti) i obogaćivanje vitaminima, mineralnim tvarima, probioticima, prebioticima bjelančevinama za zdravlje poželjnih nutrijenata, prilikom razvoja novih proizvoda $\mathrm{i} / \mathrm{ili}$ reformulacije postojećeg asortimana (www. Podravka. com). Na temelju nutritivnih profila, Podravka je krenula s reformulacijom receptura svojih kobasičarskih proizvoda sa smanjenim udjelom soli i uvođenjem zamjene za sol. Kao zamjena za kuhinjsku sol, upotrijebljena je originalno razvijena, patentirana mješavina mineralnih soli s $35 \%$ manje natrija $\left(\right.$ Salut ${ }^{\circledR}$ ) u odnosu na kuhinjsku sol, a sastoji se od natrijevog klorida, kalijevog klorida i kalijmagnezij citrata. Salut ${ }^{\circledR}$ se u ovisnosti o sastavu proizvoda i željenom okusu, može na jednak način koristiti kao i obična kuhinjska sol $u$ proizvodnji mesnih proizvoda, gotovih jela, juha, umaka, kondimenata, začina, pekarskih proizvoda (Gajari i sur., 2018.a,b, Tomić Obrdalj i sur., 2018., Zuber i sur., 2018. Ranilović i sur., 2019.), ali i kao samostalni sastojak za dosoljavanje jela.

U skladu s navedenim, cilj ovoga rada bio je validirati rokove trajnosti kobasičarskih proizvoda sa smanjenim udjelom soli i korištenjem zamjene za sol $\left(\right.$ Salut $\left.^{\circledR}\right)$, s obzirom na njihovu mikrobiološku stabilnost.

\section{Materijali i metode}

U okviru ovog rada analizirani su uzorci Podravkinih Kranjskih kobasica proizvedenih sa zamjenom za sol (Salut ${ }^{\circledR}$ ) (u daljnjem tekstu KK-sus) i Podravkinih Kranjskih kobasica proizvedenih prema „klasičnoj“ recepturi s kuhinjskom soli (kontrolni uzorci; u daljnjem tekstu KK-ku) kako bi se provjerila njihova mikrobna stabilnost.

U proizvodnji uzoraka Kranjskih kobasica namijenjenih istraživanju (KKsus i KK-ku) korištena je ista sirovina $\mathrm{u}$ jednakom tehnološkom postupku. Proizvodi su obrađeni $\mathrm{u}$ istoj komori za termičku obradu, a vakuumirani su dan nakon proizvodnje. Na taj način se eventualna odstupanja u mikrobiološkoj slici mogu povezati $s$ utjecajem različitih udjela soli u recepturama (jedna „,klasična“, a druga sa smanjenim udjelom soli), a ne razlikama prilikom procesa proizvodnje. Deklarirani rok trajnosti kontrolnih uzoraka bio je 45 dana. Kontrolni uzorci imali su deklarirani udio soli od 1,9 g, dok su KK-sus imali deklarirani smanjeni udio soli od $1,4 \mathrm{~g}$.

Ukupno je analizirano 80 pakovina kobasica (40 pakovina KK-sus i 40 pakovina $\mathrm{KK}-\mathrm{ku}$ ). Mikrobiološke analize su provedene $\mathrm{u}$ četiri navrata, $\mathrm{i}$ to 2 ., 35., 45. i 65. dana nakon proizvodnje. Svakog navedenog dana analizirano je po 10 novih pakovina KK-sus i KKku. S obzirom na tumačenje rezultata mikrobiološke analize, navedenih 10 pakovina proizvoda se promatra kao dva uzorka pri čemu je svaki uzorak sastavljen od 5 elementarnih jedinica. Proizvodi s 30 \% dužim rokom trajnosti od deklariranog, dakle 65. dana od datuma proizvodnje, analizirani su kao dodatna sigurnost za potrošače ili tzv. "zaštitni faktor". Ukupno je provedeno 140 mikrobioloških analiza.

Tijekom roka trajnosti od 45 dana, svi uzorci su ponovno analizirani i dva dana 
nakon otvaranja pakovine i čuvanja $\mathrm{u}$ hladnjaku na propisanoj temperaturi. $\mathrm{Na}$ taj se način validira i način konzumacije proizvoda deklariran na pakovini (nakon otvaranja, upotrijebiti u roku 2 dana).

Uzorci su analizirani sukladno odredbama Uredbe (EZ) br. 2073/2005 o mikrobiološkim kriterijima za hranu (Anonymous, 2005.) i sukladno preporučenim mikrobiološkim pokazateljima te kriterijima Vodiča o mikrobiološkim kriterijima za hranu (2011.) (Anonymous, 2011.).

U istraživanju su uzorci pretraženi na prisutnost ili je određen broj mikroorganizama kako je prikazano u Tabeli 1.

U mikrobiološkoj pretrazi uzoraka korištene su sljedeće ISO metode:

- HRNENISO4833-1:2013. Mikrobiologija lanca hrane -- Horizontalna metoda za određivanje broja mikroorganizama -- 1. dio: Određivanje broja kolonija pri
$30{ }^{\circ} \mathrm{C}$ tehnikom zalijevanja podloge (ISO 4833-1:2013; EN ISO 4833-1:2013) (Anonymous, 2013.).

- HRN ISO 21528-2:2008. Mikrobiologija hrane i hrane za životinje -- Horizontalna metoda za dokazivanje prisutnosti i brojenje Enterobacteriaceae -- 2. dio: Metoda određivanja broja kolonija (ISO 21528-2:2004) (Anonymous, 2008.a)

- HRN EN ISO 6888-1:2004. Mikrobiologija hrane i stočne hrane -- Horizontalni postupak brojenja koagulaza-pozitivnih stafilokoka (Staphylococcus aureus i druge vrste) -- 1. dio: Postupak primjene BairdParkerove hranjive podloge na agaru (ISO 6888-1:1999+Amd 1:2003; EN ISO 6888-1:1999+A1:2003) (Anonymous, 2004.a).

- HRN EN ISO 6579:2005/ Ispr.1:2008 Mikrobiologija hrane i hrane za životinje -- Horizontalna metoda za dokazivanje prisutnosti Salmonella spp. (ISO

Tabela 1. Mikrobiološki pokazatelji koji se pretražuju u uzorcima polutrajnih kobasičarskih proizvoda (Anonymous, 2005.), (Anonymous, 2011.).

\begin{tabular}{|c|c|c|c|}
\hline \multirow{2}{*}{$\begin{array}{c}\text { Mikroorganizmi/ njihovi toksini i } \\
\text { metaboliti }\end{array}$} & \multicolumn{2}{|c|}{$\begin{array}{l}\text { Plan } \\
\text { uzorkovanja }\end{array}$} & \multirow{2}{*}{$\begin{array}{c}\text { Kriteriji } \\
\text { (Granične vrijednosti) }\end{array}$} \\
\hline & $n$ & c & \\
\hline Listeria monocytogenes* & 5 & 0 & n.n. u 25 g \\
\hline Salmonella spp. & 5 & 0 & n.n. u $25 \mathrm{~g}$ \\
\hline Aerobne mezofilne bakterije & 5 & 2 & $\mathrm{~m}=10^{3} \mathrm{cfu} / \mathrm{g} ; M=10^{4} \mathrm{cfu} / \mathrm{g}$ \\
\hline Enterobacteriaceae & 5 & 2 & $m=10 \mathrm{cfu} / \mathrm{g} ; M=10^{2} \mathrm{cfu} / \mathrm{g}$ \\
\hline Koagulaza-pozitivni stafilokok/S. aureus & 5 & 2 & $m=10 \mathrm{cfu} / \mathrm{g} ; M=10^{2} \mathrm{cfu} / \mathrm{g}$ \\
\hline Sulfitreducirajuće klostridije & 5 & 2 & $m=10 \mathrm{cfu} / \mathrm{g} ; M=10^{2} \mathrm{cfu} / \mathrm{g}$ \\
\hline
\end{tabular}

cfu/g- (engl. colony forming unit) broj kolonija u gramu

n.n. $=$ nije nađeno

$n=$ broj elementarnih jedinica uzorka koje čine uzorak

$\mathrm{c}=$ broj jedinica uzorka, u kojima se dobivene vrijednosti ispitivanja mogu nalaziti između " $\mathrm{m}$ " i " $\mathrm{M}$ ", pri čemu se uzorak smatra prihvatljivim, ukoliko je dobivena vrijednost ispitivanja u ostalim jedinicama uzorka jednaka " $\mathrm{m}$ " ili manja od " $\mathrm{m}$ "

$\mathrm{m}$ = granična vrijednost ispod koje se svi rezultati smatraju zadovoljavajućim

$\mathrm{M}$ = granična dopuštena vrijednost iznad koje se svi rezultati smatraju nezadovoljavajućim

*obvezni mikrobiološki parametar prema Uredbi EZ br. (2073/2005), (Anonymous, 2005.) 
6579:2002/Cor 1:2004; EN ISO 6579:2002/ AC:2006) (Anonymous, 2008.b)

- HRN EN ISO 11290- 1:1999/ A1:2008. Mikrobiologija hrane i hrane za životinje -- Horizontalna metoda za dokazivanje prisutnosti i određivanje broja Listeria monocytogenes -- 1. dio: Metoda dokazivanja -- Amandman 1: Modifikacija podloge za izolaciju, test hemolize i uključivanje podataka o točnosti (ISO 11290-1:1996/Amd 1:2004; EN ISO 11290-1:1996/A1:2004) (Anonymous, 2004.b)

- HRN ISO 15213:2004. Mikrobiologija hrane i stočne hrane -- Horizontalna metoda za brojenje sulfitreducirajućih bakterija $u$ anaerobnim uvjetima (ISO 15213:2003) (Anonymous, 2003.).

Mikrobiološke pretrage provedene su u Podravkinom laboratoriju za kontrolu kvalitete, Mikrobiološkom laboratoriju mesnih proizvoda.

\section{Rezultati}

Mikrobiološkom pretragom obuhvaćeni su uzorci Kranjske kobasice proizvedeni sa smanjenim udjelom soli te, kao kontrola, uzorci Kranjske kobasice prema uobičajenoj recepturi. Rezultati su prikazani u tabelama 2-5 te slikama 1-5. Analize su obavljene $u$ predviđenim terminima (drugi, 35. i 45. dan pohrane) tijekom deklariranog roka održivosti kobasica te dva dana nakon otvaranja pakovine kobasica po svakom terminu (četvrti, 37. i 47. dan). Tako se validirala deklaracija o načinu konzumacije proizvoda (nakon otvaranja, upotrijebiti u roku 2 dana). Posljednja je mikrobiološka pretraga bila ujedno i potvrda "zaštitnog faktora“ za potrošače (65. dan). Ispitivanje je kroz rok trajnosti svaki puta provedeno na dva uzorka proizvoda, pri čemu je svaki uzorak sastavljen od 5 elementarnih jedinica uzorka.

U tabeli 2 prikazani su rezultati mikrobiološke pretrage KK-sus, na broj aerobnih mezofilnih bakterija $\left(\log _{10}\right.$ $\mathrm{cfu} / \mathrm{g})$. Izdvojen je samo taj mikrobiološki pokazatelj jer ostale bakterijske vrste tijekom analiza nisu izolirane ili im je broj bio manji od kriterija predviđenih propisima.

Tijekom promatranog razdoblja, ukupno je pet elementarnih jedinica KK-sus sadržavalo broj bakterija između graničnih vrijednosti " $\mathrm{m}$ " i " $\mathrm{M}$ ". Navedeni rezultati su dobiveni u četiri različita

Tabela 2. Broj aerobnih mezofilnih bakterija u uzorcima Kranjske kobasice sa smanjenim udjelom soli $\left(\log _{10} \mathrm{cfu} / \mathrm{g}\right)$

\begin{tabular}{|c|c|c|c|c|c|c|c|c|c|c|c|}
\hline \multirow{4}{*}{$\begin{array}{c}\text { Datum } \\
\text { početka } \\
\text { analize }\end{array}$} & \multirow{4}{*}{$\begin{array}{c}\text { Dan } \\
\text { roka } \\
\text { trajnosti }\end{array}$} & \multicolumn{10}{|c|}{ Aerobne mezofilne bakterije, $\log _{10} \mathrm{cfu} / \mathrm{g}$} \\
\hline & & \multicolumn{10}{|c|}{ Redni broj uzorka } \\
\hline & & \multicolumn{5}{|c|}{ Uzorak $1(n=5)$} & \multicolumn{5}{|c|}{ Uzorak 2 ( $n=5$ ) } \\
\hline & & $\mathrm{n} 1$ & $\mathrm{n} 2$ & n3 & n4 & n5 & n6 & n7 & n8 & n9 & $\mathrm{n} 10$ \\
\hline 31.03.17. & 2. & 2,04 & 2,34 & 2,20 & 2,14 & 1,69 & 2,07 & 1,77 & 2,00 & 1,90 & 2,00 \\
\hline 02.04.17. & $2+2$ & 2,30 & 2,07 & 2,17 & 2,27 & 2,00 & 2,25 & 2,11 & 2,17 & 2,11 & 2,11 \\
\hline 03.05.17. & 35. & 2,07 & 2,00 & 2,25 & 2,34 & 1,90 & 2,14 & 2,20 & 2,07 & 2,14 & 2,30 \\
\hline 05.05.17. & $35+2$ & 2,73 & 2,30 & 2,30 & 2,50 & 2,98 & 3,32 & 2,60 & 2,91 & 2,53 & 2,96 \\
\hline 13.05.17. & 45. & 2,47 & 2,30 & 2,85 & 3,00 & 2,53 & 2,57 & 2,30 & 3,38 & 2,47 & 2,25 \\
\hline 15.05.17. & $45+2$ & 3,00 & 2,74 & 3,00 & 3,00 & 2,68 & 2,73 & 3,74 & 3,68 & 2,64 & 2,38 \\
\hline 02.06.17. & 65. & 3,00 & 4,00 & 2,53 & 2,55 & 2,41 & 2,38 & 3,00 & 2,94 & 2,66 & 2,62 \\
\hline
\end{tabular}




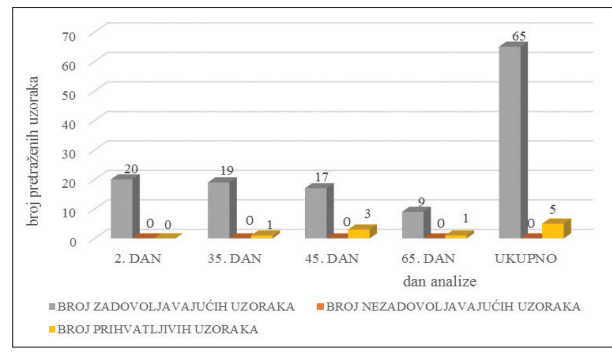

Slika 1. Broj zadovoljavajućih, prihvatljivih i nezadovaljajućih analiza uzoraka Kranjske kobasice sa smanjenim udjelom soli s obzirom na nalaz broja aerobnih mezofilnih bakterija u neotvorenim pakovinama proizvoda kao i u otvorenim proizvodima čuvanim u hladnjaku dva dana

uzorka. U jednom uzorku su dvije elementarne jedinice imale rezultate unutar vrijednosti "m" i " $\mathrm{M}$ ", a kod tri uzorka je jedna elementarna jedinica imala rezultat unutar vrijednosti " $\mathrm{m}$ " i " $\mathrm{M}$ ". Rezultat mikrobiološke analize se kod spomenuta četiri uzorka tumači kao prihvatljiv. Naime, prema odredbama propisa, kao što je to prikazano u tabeli 1., uzorak se tumači prihvatljivim jer se vrijednost ukupnog broja bakterija kod najviše dvije elementarne jedinice uzorka nalazi ispod maksimalne dopuštene " $\mathrm{M}^{\prime \prime}$, ali je veći od granične „m" vrijednosti (između vrijednosti " $\mathrm{m}$ " i " $\mathrm{M}$ "). U većini promatranih uzoraka opažamo porast ukupnog broja

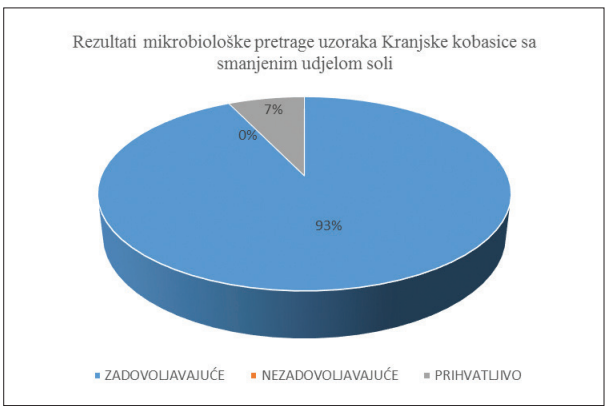

Slika 2. Ukupni udio zadovoljavajućih, prihvatljivih i nezadovoljavajućih rezultata mikrobiološke pretrage u uzorcima Kranjske kobasice sa smanjenim udjelom soli

aerobnih mezofilnih bakterija tijekom roka trajnosti pa je on najmanji 2. dan, a očekivano najveći 65. dana (izvan roka trajnosti). Također, uzorci koji su nakon otvaranja dodatno pohranjeni u hladnjaku još dva dana, što je deklarirani rok za konzumaciju kobasica, imaju povećani broj bakterija, ali za manje od 1 log što nije utjecalo na zdravstvenu ispravnost proizvoda.

$\mathrm{Na}$ slici 1. prikazan je broj zadovoljavajućih, prihvatljivih i nezadovoljavajućih uzoraka KK-sus $\mathrm{s}$ obzirom na dobivene vrijednosti aerobnih mezofilnih bakterija, a na slici 2 . njihov udio.

Tabela 3. Broj aerobnih mezofilnih bakterija u kontrolnim uzorcima Kranjske kobasice $\left(\log _{10} \mathrm{cfu} / \mathrm{g}\right.$ )

\begin{tabular}{|c|c|c|c|c|c|c|c|c|c|c|c|}
\hline \multirow{4}{*}{$\begin{array}{c}\text { Datum } \\
\text { početka } \\
\text { analize }\end{array}$} & \multirow{4}{*}{$\begin{array}{l}\text { Dan } \\
\text { roka } \\
\text { trajnosti }\end{array}$} & \multicolumn{10}{|c|}{ Aerobne mezofilne bakterije, $\log _{10} \mathrm{cfu} / \mathrm{g}$} \\
\hline & & \multicolumn{10}{|c|}{ Redni broj uzorka } \\
\hline & & \multicolumn{5}{|c|}{ Uzorak $1(n=5)$} & \multicolumn{5}{|c|}{ Uzorak 2 ( $n=5)$} \\
\hline & & $\mathrm{n} 1$ & $\mathrm{n} 2$ & n3 & n4 & n5 & n6 & n7 & $\mathrm{n} 8$ & n9 & $\mathrm{n} 10$ \\
\hline 31.03.17. & 2. & 2,07 & 1,9 & 1,95 & 2,07 & 2,27 & 2,00 & 2,00 & 2,20 & 1,90 & 2,32 \\
\hline 02.04.17. & $2+2$ & 2,30 & 2,25 & 2,84 & 2,41 & 2,34 & 2,00 & 2,20 & 2,25 & 2,47 & 2,32 \\
\hline 03.05.17. & 35. & 4,00 & 3,07 & 2,38 & 2,20 & 2,32 & 2,20 & 2,14 & 2,07 & 2,38 & 2,50 \\
\hline 05.05.17. & $35+2$ & 3,32 & 2,77 & 2,32 & 2,00 & 2,55 & 2,50 & 2,66 & 2,38 & 2,62 & 2,89 \\
\hline 13.05.17. & 45. & 2,30 & 2,34 & 2,50 & 2,88 & 2,53 & 2,57 & 2,44 & 2,64 & 2,38 & 2,55 \\
\hline 15.05.17. & $45+2$ & 2,68 & 2,69 & 2,68 & 2,71 & 2,79 & 2,74 & 2,55 & 2,66 & 2,77 & 2,73 \\
\hline 02.06 .17 & 65. & 2,80 & 2,74 & 2,34 & 2,64 & 2,47 & 2,77 & 2,73 & 2,44 & 2,50 & 2,76 \\
\hline
\end{tabular}




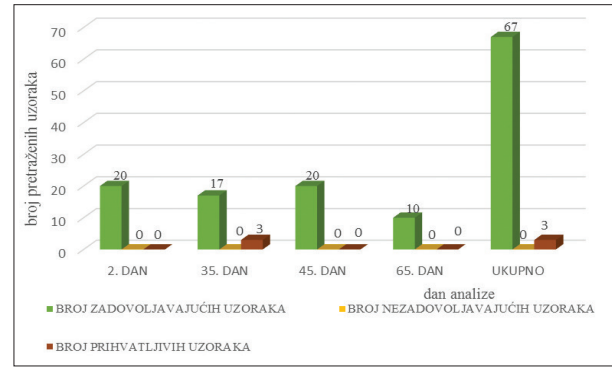

Slika 3. Broj zadovoljavajućih, prihvatljivih i nezadovoljavajućih analiza kontrolnih uzoraka Kranjske kobasice s obzirom na nalaz broja aerobnih mezofilnih bakterija u neotvorenim pakovinama proizvoda kao i u otvorenim proizvodima čuvanim u hladnjaku dva dana

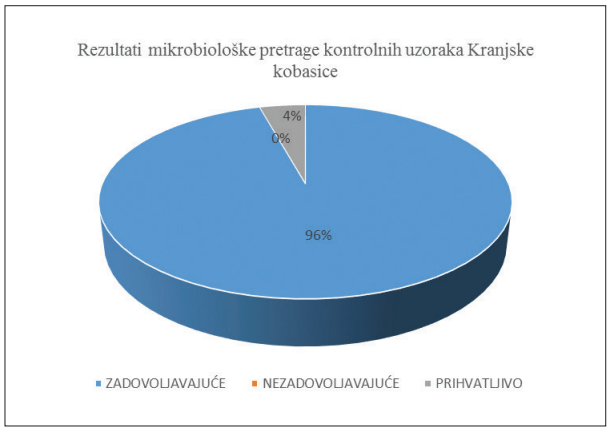

Slika 4. Ukupni udio zadovoljavajućih, prihvatljivih i nezadovoljavajućih rezultata mikrobiološke pretrage u kontrolnim uzorcima Kranjske kobasice

bakterija u kontrolnim uzorcima proizvoda (KK-ku). Ponovno je izdvojen samo ovaj mikrobiološki pokazatelj, jer ostali mikroorganizmi prilikom analiza nisu izdvojeni.

Iz podataka u tabeli 3. razvidno je da je u samo dvije pakovine uzoraka KK-ku prilikom analize 35. dana u roku trajnosti utvrđen povećani broj aerobnih mezofilnih bakterija (4 $\log _{10} \mathrm{cfu} / \mathrm{g}$,

Tabela 4. Ukupni broj aerobnih mezofilnih bakterija u uzorcima Kranjske kobasice sa smanjenim udjelom soli i u kontrolnim uzorcima Kranjske kobasice $(\log 10 \mathrm{cfu} / \mathrm{g})$

\begin{tabular}{|c|c|c|c|c|c|c|c|c|c|c|c|}
\hline \multirow{4}{*}{$\begin{array}{c}\text { Dan u } \\
\text { roku } \\
\text { trajnosti }\end{array}$} & \multicolumn{10}{|c|}{ Aerobne mezofilne bakterije, log10 cfu/g } & \multirow{4}{*}{$\mathbf{x}$} \\
\hline & \multicolumn{10}{|c|}{ Redni broj uzorka } & \\
\hline & \multicolumn{5}{|c|}{ Uzorak 1 ( $n=5)$} & \multicolumn{5}{|c|}{ Uzorak 2 ( $n=5)$} & \\
\hline & n1 & $\mathrm{n} 2$ & n3 & n4 & n5 & n6 & n7 & n8 & n9 & $\mathrm{n} 10$ & \\
\hline \multicolumn{11}{|c|}{ Kranjska kobasica sa smanjenim udjelom soli } & \\
\hline 2. & 2,04 & 2,34 & 2,2 & 2,14 & 1,69 & 2,07 & 1,77 & 2,00 & 1,9 & 2,00 & 2,01 \\
\hline 35. & 2,07 & 2 & 2,25 & 2,34 & 1,9 & 2,14 & 2,20 & 2,07 & 2,14 & 2,30 & 2,14 \\
\hline 45. & 2,47 & 2,3 & 2,85 & 3 & 2,53 & 2,57 & 2,30 & 3,38 & 2,47 & 2,25 & 2,61 \\
\hline 65. & 3,00 & 4,00 & 2,53 & 2,55 & 2,41 & 2,38 & 3,00 & 2,94 & 2,66 & 2,62 & 2,81 \\
\hline \multicolumn{11}{|c|}{ Kranjska kobasica „klasična“ receptura - kontrolni uzorak } & \\
\hline 2. & 2,07 & 1,90 & 1,95 & 2,07 & 2,27 & 2,00 & 2,00 & 2,20 & 1,90 & 2,32 & 2,07 \\
\hline 35. & 4,00 & 3,07 & 2,38 & 2,20 & 2,32 & 2,2 & 2,14 & 2,07 & 2,38 & 2,50 & 2,59 \\
\hline 45. & 2,30 & 2,34 & 2,50 & 2,88 & 2,53 & 2,57 & 2,44 & 2,64 & 2,38 & 2,55 & 2,51 \\
\hline 65. & 2,80 & 2,74 & 2,34 & 2,64 & 2,47 & 2,77 & 2,73 & 2,44 & 2,50 & 2,76 & 2,62 \\
\hline
\end{tabular}


odnosno 3,07 $\left.\log _{10} \mathrm{cfu} / \mathrm{g}\right)$. U istoj pakovini $\mathrm{u}$ uzorku 1 nakon dva dana pohrane $\mathrm{u}$ hladnjaku te ponovne analize također je utvrđen veći broj bakterija $\left(3,32 \log _{10}\right.$ $\mathrm{cfu} / \mathrm{g}) \mathrm{u}$ odnosu na dozvoljeni broj iz Vodiča o mikrobiološkim kriterijima (Anonymous, 2011.).

Na slici 3. prikazan je broj zadovoljavajućih, prihvatljivih i nezadovljavajućih analiza s obzirom na utvrđeni broj aerobnih mezofilnih bakterija, a u slici 4 njihov udio.

Kod ove skupine uzoraka samo su 3 od ukupno 70 uzoraka (4\%) prihvatljivi, a preostalih 67 uzoraka (96\%) je zadovoljavajuće mikrobiološke ispravnosti.

Skupni rezultati broja aerobnih mezofilnih bakterija u svim pretraženim uzorcima KK-sus i KK-ku tijekom promatranog razdoblja od 65 dana prikazani su u tabeli 4. Dobivene usporedne prosječne vrijednosti ukupnog broja bakterija ustvrđenih tijekom 4 analitička perioda prikazane su na slici 5 .

Prosječni je ukupni broj bakterija u KK-sus na kraju roka trajnosti bio zadovoljavajuće mikrobiološke kakvoće i iznosio 2,81 $\log _{10} \mathrm{cfu} / \mathrm{g}$. Nešto je manji broj utvrđen u KK-ku (2,62 $\left.\log _{10} \mathrm{cfu} / \mathrm{g}\right)$.

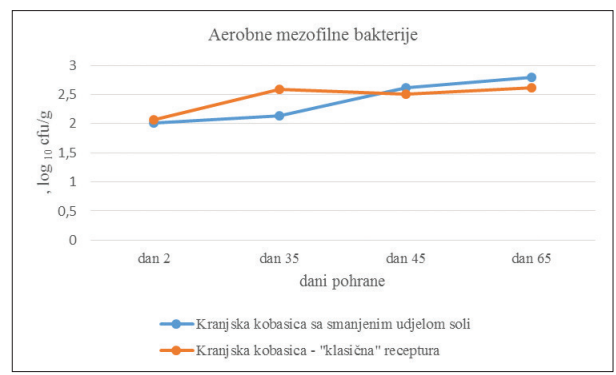

Slika 5. Prosječni broj aerobnih mezofilnih bakterija u uzorcima Kranjskih kobasica sa smanjenim udjelom soli i u kontrolnim uzorcima tijekom promatranog razdoblja od 65 dana

\section{Rasprava}

Rezultati provedenih ispitivanja pokazali su da u 80 analiziranih proizvoda nisu bile izdvojene bakterije Salmonella spp. i L. monocytogenes, niti je zabilježen porast ostalih pretraživanih bakterija, osim broja aerobnih mezofilnih bakterija.

Jednaki mikrobiološki nalaz dobiven je analizom Podravkine Kranjske kobasice i 2007. g. kada je Hrvatska udruga za zaštitu potrošača, provela Usporedne testove proizvoda uzetih $\mathrm{s}$ polica različitih trgovina (Anonymous, 2007.). Odabrana je upravo Kranjska kobasica iz razloga što pripada kategoriji prehrambenih proizvoda $\mathrm{s}$ najširom potrošnjom u Republici Hrvatskoj. U spomenutom istraživanju u uzorku Podravkine Kranjske kobasice, kao i u uzorcima koji su analizirani u ovom istraživanju, bakterije Salmonella spp. $i$ L. monocytogenes nisu izolirane, a dobivene vrijednosti za S. aureus, Enterobacteriaceae i sulfitreducirajuće klostridije su manje od njihovih dopuštenih maksimalnih koncentracija.

Prosječni broj aerobnih mezofilnih bakterija povećavao se s odmicanjem roka trajnosti u pretraženim uzorcima KK-sus i KK-ku. Prosječni ukupni broj bakterija bio je u ulaznoj analizi nešto niži u KK-sus, a 45. i 65. dana nešto veći od onoga utvrđenoga u KK-ku, no još uvijek ispod minimalne dopuštene granične vrijednosti od $3 \log _{10} \mathrm{cfu} / \mathrm{g}$.

Zelenakova i sur. (2011.) su u svom istraživanju ustvrdili prosječnu vrijednost aerobnih mezofilnih bakterija od $5 \log _{10} \mathrm{cfu} / \mathrm{g}$ u uzorcima kobasičarskih proizvoda, odnosno $4,86 \log _{10} \mathrm{cfu} / \mathrm{g}$ u uzorcima drugih vrsta proizvoda. Njihove vrijednosti bile su veće od utvrđenih prosječnih vrijednosti $u$ našem ispitivanju. Neovisno o kretanju broja aerobnih mezofilnih bakterija $u$ pojedinim uzorcima kobasica (KK-sus i KK-ku) u našem istraživanju, dobivene prosječne vrijednosti ne premašuju najveći dopušteni broj bakterija prema odredbama propisa. Jednako tako, prosječni broj bakterija bio je unutar 
dopuštenih granica u uzorcima koji su analizirani dva dana nakon otvaranja (potvrda navoda na deklaraciji).

Rezultati prikazani u ovom radu potvrdili su mikrobnu stabilnost proizvoda sa smanjenim udjelom soli korištenjem zamjene za sol $\left(\right.$ Salut $\left.^{\circledR}\right)$ te su potvrđeni dosadašnji rokovi trajnosti na ovoj vrsti proizvoda. Drugačije rezultate istraživanja mikrobiološke ispravnosti i potvrdu roka trajanja toplinski obrađenih kobasičarskih proizvoda pakiranih u vakuumu objavili su Mantis i sur. (2005.). Njihovi rezultati nisu bili zadovoljavajući te su ukazali na potrebu skraćivanja roka trajnosti $i$ nekih preinaka $u$ provedbi HACCP sustava. Isti autori $u$ analiziranim proizvodima nisu izolirali bakterije Salmonella spp., L. monocytogenes i sulfitreducirajuće klostridije, no za razliku od našeg ispitivanja, u svojim su uzorcima izolirali Enterobacteriaceae i Staphylococcus spp.

Kao što je prethodno navedeno, $\mathrm{u}$ proizvodima sa smanjenim udjelom soli korištena je jedinstvena, patentirana zamjena za sol, Salut ${ }^{\circledast}$ te je zbog njegovog specifičnog sastava, na deklaraciji proizvoda moguće dodatno istaknuti navod $25 \%$ - $40 \%$ manje natrija/soli, u odnosu na konvencionalne proizvode (proizvedene s običnom soli) i u ovisnosti o ostalim sastojcima u proizvodu.

\section{Zaključak}

Rezultati istraživanja potvrdili su da su svi analizirani uzorci Kranjske kobasice sa smanjenim udjelom soli, kao i kontrolni uzorci bili mikrobiološki ispravni sukladno važećim zakonskim odredbama. Značajno je napomenuti da u uzorcima nisu izolirani patogeni mikroorganizmi: Salmonella spp., L. monocytogenes, Enterobacteriaceae, koagulaza pozitivni stafilokoki/S. aureus i sulfitreducirajuće klostridije što je potvrda uređenog sustava sigurnosti hrane, poštivanja HACCP principa te kontinu- iranog provođenja dobre proizvođačke i higijenske prakse u proizvodnji kobasičarskih proizvoda. Ustvrđene vrijednosti aerobnih mezofilnih bakterija u uzorcima Kranjskih kobasica sa smanjenim udjelom soli u odnosu na kontrolnu skupinu ne pokazuju velika odstupanja. Dobivene prosječne vrijednosti ukupnog broja bakterija manje su od preporučenih dopuštenih vrijednosti za ovu vrstu proizvoda. Smanjeni udio soli uz korištenje zamjene za sol Salut ${ }^{\circledast}$, u recepturi za Kranjsku kobasicu nije utjecao na mikrobnu stabilnost proizvoda pa su potvrđeni postojeći rokovi trajnosti od 45 dana.

\section{Literatura}

1. ALINO, M., R. GRAU, F. TOLDRA, E. BLESA, M. J. PAGAN and J. M. BARAT (2010): Physicochemical properties and microbiology of dry-cured loins obtained by partial sodium replacement with potassium, calcium and magnesium. Meat Sci. 85, 580-588

2. Anon. (2003): Mikrobiologija hrane i stočne hrane -- Horizontalna metoda za brojenje sulfitreducirajućih bakterija u anaerobnim uvjetima (ISO 15213:2003).

3. Anon. (2004a): Mikrobiologija hrane i stočne hrane -- Horizontalni postupak brojenja koagulaza-pozitivnih stafilokoka (Staphylococcus aureus i druge vrste) - 1. dio: Postupak primjene Baird-Parkerove hranjive podloge na agaru (ISO 6888- 1:1999+Amd 1:2003; EN ISO 68881:1999+A1:2003).

4. Anon. (2004b): Mikrobiologija hrane i hrane za životinje - Horizontalna metoda za dokazivanje prisutnosti i određivanje broja Listeria monocytogenes -- 1. dio: Metoda dokazivanja -Amandman 1: Modifikacija podloge za izolaciju, test hemolize i uključivanje podataka o točnosti (ISO 11290-1:1996/Amd 1:2004; EN ISO 11290 1:1996/A1:2004).

5. Anon. (2005): Uredba (EZ) br. 2073/2005 od 15 studenoga 2005. o mikrobiološkim kriterijima za hranu.

6. Anon. (2007): Usporedni testovi proizvoda. Hrvatska udruga za zaštitu potrošača.

7. Anon. (2008a): Mikrobiologija hrane i hrane za životinje -- Horizontalna metoda za dokazivanje prisutnosti i brojenje Enterobacteriaceae -- 2. dio: Metoda određivanja broja kolonija (ISO 215282:2004).

8. Anon. (2008b): Mikrobiologija hrane i hrane za životinje - Horizontalna metoda za dokazivanje 
prisutnosti Salmonella spp. (ISO 6579:2002/Cor 1:2004; EN ISO 6579:2002/AC:2006).

9. Anon. (2011): Vodič o mikrobiološkim kriterijima za hranu (3. izdanje, MPRiRR, 2011).

10. Anon. (2013): Mikrobiologija lanca hrane -Horizontalna metoda za određivanje broja mikroorganizama -- 1. dio: Određivanje broja kolonija pri $30{ }^{\circ} \mathrm{C}$ tehnikom zalijevanja podloge (ISO 4833-1:2013; EN ISO 4833-1:2013).

11. Anon. (2014a): Strateški plan za smanjenje prekomjernog unosa kuhinjske soli u Republici Hrvatskoj 2015.-2019.

12. Anon. (2014b): Znanstveno mišljenje o učinku smanjenog unosa kuhinjske soli u prehranu ljudi. $\mathrm{HAH}$.

13. Anon. (2014c): Letak Manje soli - više zdravlja. HAH, Ministarstvo zdravlja, Ministarstvo poljoprivrede, HZJZ, Hrvatsko društvo za hipertenziju, Hrvatsko društvo za aterosklerozu, Hrvatsko kardiološko društvo.

14. BIDLAS, E. and R. J. W. LAMBERT (2008): Comparing the antimicrobial effectiveness of $\mathrm{NaCl}$ and $\mathrm{KCl}$ with a view to salt/sodium replacement. Int. J. Food Microbiol. 124, 98-102.

15. CEPANEC, K., S. VUGRINEC, T. CVETKOVIĆ and J. RANILOVIĆ (2017): Pottasium chloride-based salt substitutes; A critical review with a focus on the patent literature. Compr. Rev. Food Sci. F. 16, 881-894.

16. DESMOND, E. (2006): Reducing salt: A challenge for the meat industry. Meat Sci. 74, 188-196.

17. DOKO JELINIĆ, J., A. NOLA i D. ANDABAKA (2010): Prehrambena industrija - utjecaj soli na potrošače, Znanstveni skup Kardiovaskularno zdravlje. Prehrana i sol. Zagreb, 21. studenoga 2008. Knjiga sažetaka radova 11-12.

18. GAJARI, D., J. RANILOVIĆ and H. TOMIĆ OBRDALJ (2018a): Culinary application of the innovative salt substitute in preparation of bakery products. Book of Abstract of $6^{\text {th }}$ International Congress of Nutritionists, 26.-28.10.2018. Zagreb, Hrvatska (1), p. 158.

19. GAJARI, D., J. RANiloviĆ, H. TOMIĆ OBRDALJ, LJ. PRIMORAC and T. CVETKOVIĆ (2018b): Sensory profiles and acceptability of an innovative salt substitute in comparison with traditional salt samples evaluated by trained and consumer panels. Book of Abstracts, of $8^{\text {th }}$ European Conference on Sensory and Consumer Research (EUROSENSE 2018), 2.5.9.2018. Verona, Italija. (2), P1.68

20. GELABERT, J., P. GOU, L. GUERRERO and J. ARNAU (2003): Effect of sodium chloride replacement on some characteristics of fermented sausages. Meat Sci. 65, 833-839.
21. https://www.podravka.hr/kompanija/odgovornost/ potrosaci/podravkina-nutritivna-strategija/ (Pristupljeno: 25.4.2019.).

22. KAIĆ-RAK, A., J. PUCARIN - CVETKOVIĆ, I. HEIM i B. SKUPNJAK (2009): Razlozi za smanjenje soli u prehrani i potencijalni učinak na zdravlje populacije - preporuke svjetske zdravstvene organizacije. Acta Med. Croat. 64, 129-132.

23. KEAST, R. (2010): Salt; Health; Functionality and Flavor Nu-Tek Products. Literature Review Salt Taste, June 1. http://www.malabarsuperspice. com/docs/salt_DrKeast_Literature_Review.pdf (pristupljeno 10.9.2017.)

24. LIEM, D. G., F. MIREMADI and R. S. J. KEAST (2011): Reducing sodium in foods: The effect on flavor. Nutrients 3, 694-711.

25. MANTIS, F. N., I. TSACHEV, O. SABATAKOU, A. R. BURRIEL, A. VACALOPOULOS and S. B. RAMANTANIS (2005): Safety and shelf-life of widely distributed vacuum packed, heat treated sausages. Bulg. J. Vet. Med. 8, 245-254.

26. REINER, Ž. i B. JELAKOVIĆ (2010): Manje soli više zdravlja: mogućnosti prevenciji u Hrvatskoj. Acta Med. Croatica 64, 79-81.

27. RANILOVIĆ, J., D. GAJARI, H. TOMIĆ OBRDALJ, T. CVETKOVIĆ and I. COLIĆ BARIĆ (2019): Salt reduction: Translation of consumer expectations into wishful taste product attribute. Int. J. Food Eng. 5, 43-49.

28. REDDY, K. A. and E. H. MARTH (1991): Reducing the sodium content of foods: A review. J. Food Protect. 54, 138-150.

29. RUUSUNEN, M. and E. POULANNE (2005): Reducing sodium intake from meat products. Meat Sci. 70, 531-541.

30. TOMIĆ OBRDALJ, H., D. GAJARI and J. RANILOVIĆ (2018): Comparison of saltiness and palatability of salt reduced soup by different approaches. Book of Abstracts of $9^{\text {th }}$ International Congress of Food Technologist, Biotechnologist and Nutritionist, 3.-5.10.2018. Zagreb, Hrvatska, P. 59.

31. ZELENAKOVA, L., S. KUNOVA and L. LOPAŠOVSKY (2011): Evaluation of microbiological quality of cooked meat products during their shelf life. Maso International Brno 1, 15-20.

32. ZUBER, A. Đ., J. RANILOVIĆ, D. GAJARI and L. ZEMLJAK (2018): Influence of the innovative salt substitute on quality of dry fermented sausage. Book of Abstracts of $9^{\text {th }}$ International Congress of Food Technologist, Biotechnologist and Nutritionist, 3.-5.10.2018. Zagreb, Croatia, p. 169.

33. ŽLENDER, B. (2009): Smanjenje koncentracije soli u mesnim proizvodima. Meso XI, 189-195. 


\section{Microbial stability of sausage products with reduced salt content}

Lidija ZEMLJAK, univ. mag. med. vet., Jasmina RANILOVIĆ, PhD, Scientific Associate, Andreja Đurica ZUBER, PhD, Vesna POPIJAČ, MSc, Podravka d.d., Koprivnica, Croatia; Josip MADIĆ, DVM, PhD, Academican, Lidija KOZAČINSKI, DVM, PhD, Full Professor, Faculty of Veterinary Medicine, University of Zagreb, Croatia

The objective of this paper was to validate the shelf life of a product with reduced salt content containing a salt substitute, with regards to its microbiological stability. Microbiological analyses were carried out on Kranj sausage (Kranjska kobasa), as a representative of the group of semi-permanent sausage products. The control sample was manufactured according to the "classic" formula. Ten packets of the control sample were analysed immediately after vacuuming, then within the stated expiration period (day 35 ), on the expiration date ( 45 days from the date of production) and 65 days from date of production. All samples were also analysed two days after opening the packet and storage of the product in the refrigerator at the prescribed temperature. This also validates the manner of product consumption as declared on the packaging (after opening, use within two days). The version of the Kranj sausage with reduced salt content was also tested in the same manner. The study covered the following microorganisms: aerobic mesophilic bacteria, Enterobacteriaceae, positive staphylococci coagulase/S. aureus, Salmonella spp., Listeria monocytogenes, and sulfite-reducing clostridia. ISO methodology was applied in the analysis. Testing the microbial stability of the reduced salt product was performed on the basis of 140 microbiological analyses. In samples with reduced salt content and in control samples, no bacteria were isolated from the genus Salmonella or Listeria monocytogenes, nor were there any increases in the numbers of other microorganisms, with the exception of aerobic mesophilic bacteria. Three samples (4\%) produced according to the "classic" recipe gave an acceptable result for aerobic mesophilic bacteria, while five samples $(7 \%)$ with reduced salt content were readily acceptable according to the regulations. The analysis of all remaining samples was satisfactory, and no unsatisfactory result was obtained. All the analysed samples were microbiologically suitable throughout the entire shelf life of the product. Reduced salt content was achieved with salt substitution $\left(\right.$ Salut $\left.{ }^{\circledR}\right)$, which did not affect the microbial stability of the product. The absence of pathogenic microorganisms in the analysed samples confirms the regulated food safety system, compliance with the HACCP principles and continuous implementation of good manufacturing and good hygiene practices.

Key words: microbial stability; sausage products; decreased salt content; salt substitution; aerobic mesophilic bacteria 